\title{
The Right of Prisoner During the Covid-19: Pro and Cons in Indonesia
}

\author{
Pulung Widhi Hari Hananto ${ }^{1}$, Nanik Trihastuti ${ }^{2}$, Daniel Rene Kandou ${ }^{3}$, \\ Ramadhan Catur Bismono ${ }^{4}$ \\ \{hananto.pulung@live.undip.ac.id ${ }^{1}$, naniktrihastuti@gmail.com ${ }^{2}$, \\ danielrenekandou@students.undip.ac.id ${ }^{3}$, ramacaturb@students.undip.ac.id $\left.{ }^{4}\right\}$ \\ Universitas Diponegoro, Semarang, Indonesia ${ }^{1}$, Universitas Diponegoro, Semarang, Indonesia ${ }^{2}$, \\ Universitas Diponegoro, Semarang, Indonesia ${ }^{3}$, Universitas Diponegoro, Semarang, Indonesia ${ }^{4}$
}

\begin{abstract}
Covid-19 has brought significant changes to all segments of life in the international community. Almost all countries highly anticipate suppressing the spread of this pandemic. The places of detention have the potential to become a new epicenter and on the one hand, this will endanger the lives of the prisoners instead their human rights. in the matter to face these issues, Indonesia releases the policy that implemented the inmates' program that mimics the pros and cons in society. This article is using normative research method. Later on, this article will discuss the pros and cons in regard the release of prisoner program and juvenile inmates in Indonesia during this global pandemic outbreak. Furthermore, it will also examine with comprehensively the legality of prisoner right as impacted the Covid-19.
\end{abstract}

Keywords: Right of Prisoners, Covid-19, Indonesia.

\section{Introduction}

The saga of Covid-19 has always to be popular culture to be addressed. Per may 2020, The global pandemic has continued to take over all segment of international segments, from the health crisis to the domestic economy. As the impact, almost every international communities had impacted by this pandemic. Many countries had released the urgent policies to boldly anticipate the spreading of COVID 19 instead imposed the travel ban and also declared the lockdown [1]. As the impact, it considerably almost every international communities had impacted by this pandemic, include Indonesia.

As of April 13, 2020, President Joko Widodo has determined the COVID-19 pandemic to be a national disaster through Presidential Decree No.12 of 2020 concerning the Designation of Non-Natural Disasters of the Spread of Covid-19 as a National Disaster. This means that Indonesia has faced an emergency condition. The very fast spread of COVID-19 is inversely proportional to Indonesia's overcapacity prisons [2]. This condition of excess capacity encourages the state to release prisoners because after all the state must guarantee the right to life of each of its citizens in the midst of this COVID-19 pandemic. In line with the UN high commission for Human Rights regarding the release of prisoners with overcapacity conditions by establishing a better life outside prison. In contrast, the society would be uncertainty and possibly not open to accept the juvenile 'inmates' and release of the prisoner program in response to the Covid-19 outbreak. 


\section{Methods}

The current research has the basis on the law related to the protection of prisoner right during the pandemic era. Specifically, the author utilizes Indonesian National law and other supported regulations (especially international instruments such as convention) to elaborates and understands the protection of prisoner's right. Besides, the author also uses the secondary sources data such as legal writings that have interpreted the primary sources, including books, scientific paper, working paper and journals accessible online.

\section{Result and Discussion}

\subsection{The Legality and the Protection to the Life in Prison and/or Places of Detention}

The human rights of prisoners under international law are clearly protected. The rights of prisoners are recognized by States from principal international human rights instruments to subsidiary international documents, constituting an authoritative guide to binding treaty standards and reaffirm the tenet that prisoners retain fundamental human rights.

\section{a. Universal Declaration of Human Rights}

The Universal Declaration of Human Rights (UDHR) is one of the most important documents in the development of human rights law, which was adopted by the United Nations General Assembly as Resolution 217 on 10 December 1948. The UDHR was the first step in the formulation of the International Human Rights treaties consisted the International Covenant on Civil and Political Rights (ICCPR) and the International Covenant on Economic, Social and Cultural Rights (ICESCR), which came into force in 1976. Although the UDHR is not legally binding, the protection of the rights and freedoms set out in the declaration has been incorporated into many national constitutions and domestic legal frameworks. Some argue that it has become binding as a part of customary international law [3].

With regards to rights of prisoners, Article 3 of the UDHR provides that "Everyone has the right to life, liberty and security of person." Moreover, regarding their treatment, Article 5 the UDHR provides that "No one shall be subjected to torture or to cruel, inhuman or degrading treatment or punishment ..." The UDHR uses the phrase "No one" and the term "everyone" to emphasize the rights attained to people without making exclusion to some categories of people [4].

\section{b. The International Covenant on Civil and Political Rights}

The ICCPR is the most comprehensive and well-established UN treaty on civil and political rights. The ICCPR was adopted by the UN General Assembly in 1966 and came into force in 1976 once it had 35 ratifications. As of September 2019, the Covenant has 173 parties. As of its implementation, the ICCPR imposes duties upon States in the international plane to protect the rights therein at the municipal level [5].

The protection of prisoners includes the prisoner's right to life. Article 6 of the ICCPR explicitly states that "Every human being has the right to life. This right shall be protected by law. No one shall be arbitrarily deprived of his life." This right has been described by the 
Human Rights Committee as a 'supreme right'(Based on UN Human Rights Committee (HRC), General comment no. 31 [80], The nature of the general legal obligation imposed on States Parties to the Covenant, 26 May 2004, CCPR/C/21/Rev.1/Add.13, para. 1). In its General Comment, State Parties also have a heightened duty to protect the lives of prisoners, since by arresting, detaining, imprisoning or otherwise depriving individuals of their liberty, the responsibility to the protection of their lives is assumed. The obligation to uphold the right to life of prisoners includes providing necessary medical care and appropriate regular monitoring of their health (Based on UN Human Rights Committee (HRC), General comment no. 31 [80], the nature of the general legal obligation imposed on States Parties to the Covenant, 26 May 2004, CCPR/C/21/Rev.1/Add.13, para. 25. Lantsova v. Russian Federation (CCPR/C/74/D/763/1997), para. 9.2).

In addition, Article 10 of the ICCPR mandates "all persons deprived of their liberty shall be treated with humanity and with respect for the inherent dignity of the human person." It also requires that "the reform and social rehabilitation of prisoners" be an "essential aim" of imprisonment (Based on UN General Assembly, International Covenant on Civil and Political Rights, 16 December 1966, United Nations, Treaty Series, vol. 999 (ICCPR), p. 171, Art. 10). The article also applies to persons in detention or correction facilities, prisons, hospitals, or any other facilities in which a person is deprived of their liberty. This provision therefore enforces article 7 of the ICCPR, which prohibit torture or other cruel, inhumane or degrading treatment (ICCPR, Art. 7), which are conducted by guaranteeing the person deprived of liberty with the same conditions for free person.

\section{c. The International Covenant on Economic, Social and Cultural Rights}

Along with the ICCPR, the International Covenant of Economic, Social and Cultural Rights is part of the International Bill of Human Rights and entered into force in 1976. Within the UN System, the Right to Health was firstly guaranteed in Article 12 ICESCR, which affirms "the right of everyone to the enjoyment of the highest attainable standard of physical and mental health" (Based on UN General Assembly, International Covenant on Economic, Social and Cultural Rights, 16 December 1966, United Nations, Treaty Series, vol. 993 (ICESCR), p. 3, Art. 12).

In its General Comment, States are under the specific legal obligation to respect the right to health by provides equal access to 'preventive, curative and palliative health services' for prisoners or detainees (Based on UN Committee on Economic, Social and Cultural Rights (CESCR), General Comment No. 14: The Right to the Highest Attainable Standard of Health (Art. 12 of the Covenant), 11 August 2000, E/C.12/2000/4, para. 35).

\section{d. Other International instruments}

Other International instrument refers to international instruments codified in numerous international resolutions that serve as guidance and principles, and are rather "non-binding" soft law instruments.

1) The UN Standard Minimum Rules. The Standard Minimum Rules for the Treatment of Prisoners (adopted in 2015 as the Nelson Mandela Rules) is a standard adopted by the UN General Assembly as efforts in providing guidelines to State's national legislation with respect to any person in any form custody. The standard also aids the reinforcement of States' obligation to provide medical care and treatment for sick prisoners (Based on UN General Assembly, United Nations Standard Minimum Rules 
for the Treatment of Prisoners (the Nelson Mandela Rules): resolution/adopted by the General Assembly, 8 January 2016, A/RES/70/175; Rule 24-27).

2) Body of Principles for the Protection of All Persons under Any Form of Detention or Imprisonment. The Body of Principles for the Protection of All Persons under Any Form of Detention or Imprisonment was adopted without vote by the UN General Assembly on December 9, 1988. This instrument consists of principles which govern the implementation of human rights towards detainees in any form of detention. These principles has been cited within international jurisprudence, and used as a basis for defining standards within international law [6].

3) Basic Principles for the Treatment of Prisoners. The Basic Principles for the Treatment of Prisoners on the hand was proclaimed and adopted by the UN General Assembly on December 14, 1990. This differs to the previous principles to the content that this governs the rights of prisoners. According to the principles, "Prisoners shall have access to the health services available in the country without discrimination on the grounds of their legal situation (Based on UN General Assembly, Basic Principles for the Treatment of Prisoners: resolution/adopted by the General Assembly, 28 March 1991, A/RES/45/111, para. 9).

\subsection{The Rights of Prisoners in Indonesia}

Under Article 1(7) of this Act, prisoners are convicts who have served a sentence of loss of freedom in prison. Meanwhile, the definition of a convicted person is someone who is convicted based on a court decision that is final and binding.

The rights of prisoners regulated in Article 14 paragraph (1) of the Correctional Law are as follows: i. perform worship according to their religion or belief; ii. Receive care, both spiritual and physical care; iii. Education and teaching; iv. Proper health services and food; v. submit a complaint; vi. Obtain reading material and other mass media broadcasts that are not prohibited; v. receive a wage for the work performed; vi. Receive visits from family, legal counsel, or certain other people; vii. reduced sentence (remission); viii. the opportunity to assimilate including leave to visit family; ix. parole; $x$. a leave before being released; and other rights in accordance with the prevailing laws and regulations.

More specifically, the rights of prisoners are further regulated in Government Regulation no. 32 of 1999 concerning Terms and Procedures for the Implementation of the Rights of Correctional Assistants ("PP 32/1999") as amended by Government Regulation No. 28 of 2006 ("PP 28/2006"), and amended a second time by Government Regulation No. 992012 ("PP 99/2012").

\subsection{Covid-19 vs. The Rights of Prisoners}

Basd on Based on World Health Organization. Novel Coronavirus (2019-nCoV): situation report, 19. P.1. World Health Organization (2020). The global phenomenon of Covid-19 pandemic is at the center of the world attention since its outbreak in the early months of 2020. Although not the first in the history of mankind, it is the first pandemic to occur in the framework of the modern international society. Therefore, the phenomenon is unprecedented for many international institutions, organizations, and even within the states itself. Furthermore, the implementation of "new normal" policy indicates that the pandemic can no longer be considered as an emergency situation, and that adaptation to the environment is needed. 
Based on United Nations, COVID-19 and Human Rights: We are all in this together. p.2. United Nations (2020) had reported that states are at risk of disrespecting human rights in its precaution measures to prevent the spread of pandemic. This risk is present in various measures such as lockdowns and restriction of movement to slow the spread of the virus, which in turn, may reduce the enjoyment of human rights for many people.

Further, the situation may result in inequalities, especially in places such as prisons, detention or correction facilities which are already lacking in hygiene and social services, and places where information and prevention measures such as testing, hand-washing, selfisolation and quarantine is difficult to be implemented (Based on United Nations. COVID-19 and Human Rights: We are all in this together. p.2. United Nations (2020); United Nations. A UN framework for the immediate socio-economic response to COVID-19. p.6. United Nations (2020). This situation affects the enjoyment of human rights and dignity of the prisoners.

The international legal order is structured around the principle of state sovereignty, i.e. on the independence of states. Internally, state authorities have the monopoly on the legitimate use of physical force' [7]. The state powers, nonetheless, are not without limits. International human rights conventions impose conditions under which a derogation to human rights can be justified [8]. Besides the requirement of notification, there are non-degradable rights such as the right to life (Based on ICCPR, Art.6), prohibition of torture and ill treatments (Based on ICCPR, Art.7), prohibition of slavery (Based on ICCPR, Art.8), and no punishment without law (Based on ICCPR, Art.15).

$\mathrm{UN}$ is calling on countries to adopt a more cooperative, global and human rights-based approach to the pandemic, including the treatment of prisoners (Besed on UN General Assembly, Global solidarity to fight the coronavirus disease 2019 (COVID-19), A/RES/74/270). States are obliged to take preventive measures in accordance with existing international human rights norms (Based on UN General Assembly, Basic Principles for the Treatment of Prisoners, A/RES/45/111 (14 December 1990): 1) Conduct an immediate, unconditional release of all prisoners whose incarceration is illegal or Arbitrary under international law; 2) Abandon or exclude detention as a sanction for persons found to be in breach of Covid-19 related measures; 3) Reduce overcrowding, through a review of the prison population and consideration of alternative sentencing to imprisonment for misdemeanor; 4) Considering an alternative to pre-trial detention such as bail, release under judicial control, or others; 5) Considering for immediate release persons detained for misdemeanor and low-level crime, with certain condition; 6) Consider for immediate release of all persons held in immigration detention centers and closed refugee camps with a view to reducing their populations to the lowest possible level; 7) Consider for immediate temporarily release on bail or otherwise all persons detained without charge or trial and held on various non-criminal grounds, such as persons held pending deportation or extradition; 8) Ensure that the conditions of detention of all those who remain in prison meet international human rights standards. Some States had taken measures to reduce overcrowding in prisons, detention or correctional facilities by conducting early release in attempt to protect the health of prisoners and staff.

These are important factor as the spread of Covid-19 is closely dependent on the human behavior and interactions. There are also documented outbreaks of respiratory disease in jails and prisons in many countries [9]. 


\subsection{Pro and Contra}

The total population of incarcerated persons in prisons are estimated at 11 million, with approximately 124 prisons worldwide are overcrowded. Philippines has imprisoned 215000 people in facilities with maximum occupancy of 40000 . Myanmar has population of approximately 92000 inmates across 100 prisons and labor camps, served by medical staff estimated to consist of 30 doctors and 80 nurses [10].

Based on the World Health Organization. Laboratory testing strategy recommendations for COVID-19: Interim guidance (2020). In many states, the prevention measures to stop the spread of Covid-19 have reduced individual rights. The public health crisis concern is the major justification for the implementation of the restriction. However, in the prison context, the legislation and the health regulation do not guarantee the fulfillment of its purpose, which is to interrupt the transmission of Covid-19. Globally, there are widespread concerns about large COVID-19 epidemics sweeping through the incarcerated populations in China, Brazil, India, Indonesia, and several African nations, leading to calls for parole or early release [11]. The synergistic combination of the high-transmissibility of Covid-19 and the high flow into and out of jails will continue to threaten those imprisoned the staff, and the larger community [12].

Based on World Health Organization, "WHO Indonesia Situation Report -21," (2020). As of 19 August, the Government of Indonesia announced 144945 confirmed cases of COVID-19, 6346 deaths and 98657 recovered cases from 484 districts across all 34 provinces. Most confirmed cases were in Java: DKI Jakarta followed by East Java, Central Java, and West Java. South Sulawesi is the only province outside Java that has one of the highest numbers of confirmed cases. Java contributed 58\% of the total cases in Indonesia.

Besed on World Health Organization, "WHO Indonesia Situation Report - 20," (2020). President Joko Widodo has ordered nationwide enforcement of COVID-19 protocols, such that violations are subject to legal sanctions. The rules established by the Presidential Instruction (Instruksi Presiden) No. 6/2020 seek to improve public compliance with health protocols to reduce the spread of COVID-19. All regional heads - governors, mayors and regents - are required to formulate and issue policies for the prevention of COVID-19 and to enforce sanctions for violations of policies. The sanctions may range from a written warning and community service to fines and temporary suspension of businesses and organizations.

\subsection{The Effectively of Indonesia Government to handle this issue}

President Joko Widodo has ordered nationwide enforcement of COVID-19 protocols, such that violations are subject to legal sanctions. The rules established by the Presidential Instruction (Instruksi Presiden) No. 6/2020 seek to improve public compliance with health protocols to reduce the spread of COVID-19.

All regional heads - governors, mayors and regents - are required to formulate and issue policies for the prevention of COVID-19 and to enforce sanctions for violations of policies. The sanctions may range from a written warning and community service to fines and temporary suspension of businesses and organizations (World Health Organization, "WHO Indonesia Situation Report - 20, " (2020). 
As a member of WHO, Indonesia has its sets of obligation in accordance with IHR (2005). Furthermore, its obligation is not only limited to the cooperation in the precautionary measures to prevent Covid-19, but also to its human rights obligation (Based on World Health Organization. COVID-19 Response. A73/CONF./1 Rev.1, (2020). Various measures have been implemented to stop the spread of Covid-19. On 04 May, the President announced a new plan to manage the COVID19 pandemic, consisting of the following:[13] i) Thorough evaluation of the large-scale social restriction (PSBB) that has been in place in 12 districts and four provinces across the country; ii) Setting easily measurable targets in terms of PCR testing to be conducted, aggressive contact tracing and social isolation policies by provinces and districts that imposed PSBB; iii) Stricter monitoring of migrant workers who have recently returned from overseas, pilgrims who attended the Islamic gathering in South Sulawesi, factory workers, and people from urban centers who returned to their hometown ahead of Eid; iv) The social safety net programmed to reach low-income families; v) A new hotline to process complaints of citizens about public services.

The discourse on the release of prisoners due to corruption has generated a polemic in the community. Efforts to reduce penalties for corruptors were carried out by revising Government Regulation No. 99/2012 concerning Terms and Procedures for the Implementation of Community Development Rights. However, President Joko Widodo emphasized that there would be no release of corrupt convicts. The release of prisoners due to COVID-19 is due to general criminal reasons. The Minister of Law and Human Rights, Yasonna Laoly at least specified four criteria for prisoners who could be released through the revision of the PP. These criteria are prisoners in narcotics cases with the condition that they have a prison term of 5 to 10 years who have served two-thirds of their detention period, the proposed release applies to convicts of corruption cases aged 60 years and over and has served $2 / 3$ of their detention period, and for a special criminal convict who is chronically ill and has served $2 / 3$ of his prison term [14]. This prisoner program needs to be monitored closely and firmly in dealing with the impact that has occurred as a result of this policy because it turns out that several prisoners who were released have returned to be involved in committing criminal acts because the convict's crime has created a growing fear in the community.

\section{Conclusion}

The policy of the Minister of Justice and Human Rights to implement this inmates' policy can be said to be reaping the pros and cons of Indonesian society. The pro consideration withholding the inmates' program is because they see that prisons can have the possibility to become epicenter of the spread of corona. On the one hand, this is also a legal step to ensure the survival and human rights of prisoners. On the contra side, there was rejection due to unclear formulations of which prisoners could be returned to the community and very constrained by the disintegration between the Central Government and Local Governments in applying for this inmates' program.

\section{Acknowledgment}

Acknowledgment. The author would like to credit and thanks to Universitas Diponegoro, Semarang. Another thanks to The International Conference on Environmental and Technology 
of Law Business and Education on Post Covid-19 in edition 2020, in order to review, advice and accept this paper. Next, we would like to thank the Minister of Justice and Human Right of who's giving the data was used by the author as reference material that serves to provide the supporting data for analysis of this article. As the result, this study is highly qualification and can be published for the advancement of social science, especially in Human Rights Covid-19 Studies and public policy.

\section{Reference}

[1] P. Widhi and H. Hananto, "LEGAL OPINION : Does China Can Be Sued for The Global Pandemic ?," vol. 3, no. 2, pp. 232-239, 2020.

[2] C. Indonesia, "Jokowi Tetapkan Corona Sebagai Bencana Nasional," CNN Indonesia, 2020. [Online]. Available: https://www.cnnindonesia.com/nasional20200413180042-20493149/jokowi-tetapkan-wabah- corona-sebagai-bencananasional ,. [Accessed: 25-Aug-2020].

[3] M. Nasir et al., Rencana Strategis 2016-2020 Badan Amil Zakat Nasional. Jakarta: Badan Amil Zakat Nasional (BAZNAS), 2018.

[4] I. Danjuma, B. State, U. Gadau, R. Nordin, and M. M. Muhamad, "Rights of Prisoners under International Law: Rights against Forced Labour; Ill Treatments or Punishments; and Right to Work and Receive Wages," no. August, 2017.

[5] S. Joseph, The International Covenant on Civil and Political Rights. New York: Oxford University Press, 2013.

[6] R. Lines, "The right to health of prisoners in international human rights law," Int. J. Prison. Health, vol. 4, no. 1, pp. 3-53, 2008.

[7] M. Weber, From Max Weber: Essays in Sociology. London: Oxford University Press, 1946.

[8] A. Lebret, "COVID-19 pandemic and derogation to human rights," J. Law Biosci., vol. 7, no. 1, pp. $1-15,2020$.

[9] S. A. Kinner et al., "Prisons and custodial settings are part of a comprehensive response to COVID-19," Lancet Public Heal., vol. 5, no. 4, pp. e188-e189, 2020.

[10] T. Burki, "Prisons are 'in no way equipped' to deal with COVID-19," Lancet, vol. 395, no. 10234, pp. 1411-1412, 2020

[11] W. P. R. Programme, COVID-19 in prisons: a major public health risk. London: Birkbeck, 2020.

[12] E. Barnert, C. Ahalt, and B. Williams, "Prisons: Amplifiers of the COVID-19 Pandemic Hiding in Plain Sight," Am. J. Public Heal., pp. 964-966, 2020.

[13] Jakarta Globe, "Jokowi's New Five-Point Plan Anticipates Second Wave of Pandemic," Jakarta Globe, 2020.

[14] CNN Indonesia, "Jokowi: Pembebasan Napi Koruptor Tak Pernah Dibahas di Rapat," CNN $\begin{array}{lll}\text { Indonesia, } & \text { [Online]. } & \text { Available: }\end{array}$ https://www.cnnindonesia.com/nasional/20200406095618-12-490649/jokowi-pembebasannapi-koruptor-tak-pernah-dibahas-di-rapat. [Accessed: 25-Aug-2020]. 